Pak. j. sci. ind. res. Ser. B: biol. sci. 2020 63B(3) 94-108

\title{
Review
}

\section{A Review of Taxonomic Perspective of Diversity in Gymnosperms of Kashmir Himalaya}

\author{
Abdul Rashid Dara, Lubna Andleeb ${ }^{\mathrm{b} *}$, Ghulam Hassan Darc, Mohammad Rafiq Wania, \\ Afroza Akhter ${ }^{a}$, Naseer Hussain Shah ${ }^{a}$ and Irfana Amin ${ }^{a}$ \\ a'Department of Botany, Abdul Ahad Azad Memorial Government Degree College Bemina-190018, \\ Srinagar, Jammu and Kashmir, India \\ ${ }^{b}$ Department of Botany, Government Degree College Ganderbal-191201, Jammu and Kashmir, India \\ ${ }^{\mathrm{c} S}$ School of Biosciences and Biotechnology, Baba Ghulam Shah Badshah University, Rajouri-185234, \\ Jammu and Kashmir, India
}

(received May 28, 2018; revised January 11, 2019; accepted January 21, 2019)

\begin{abstract}
Varied floristic works relevant to Kashmir Himalaya were thoroughly examined to compile taxonomic contributions of various taxonomists viz. a viz. diversity in gymnosperms of this region. Extensive field surveys and standard taxonomic methods were used to locate, collect, identify and prepare an updated list of the target group. A total of 25 species of gymnosperms belonging to 13 genera in 6 families and 4 orders have been documented from the Kashmir Himalaya. Wild gymnosperms are represented by 11 species with conifers forming the most dominant group. Among families, Pinaceae is highest represented with 6 species, while Taxaceae is least represented. Cultivated gymnosperms exceed wild growing species, and Cupressaceae is most dominant with 9 species whereas Ginkgoaceae is least represented. Out 25 species 19 ( 7 wild +12 cultivated) are trees, 5 ( 3 wild +2 cultivated) are shrubs and only 1 is sub-shrub.
\end{abstract}

Keywords: floristic diversity, gymnosperm, Kashmir Himalaya, cultivation

\section{Introduction}

Gymnosperms are distributed throughout the world with about 1079 species in 12 families and approx. 83 genera (Christenhusz and Byng, 2016). The three 'nonconifer' groups comprise about 337 species of cycads in 10 genera, one extant ginkgophyte, and 111 species of gnetophytes in three genera (Christenhusz and Byng, 2016). Farjon (2010) has reported about 615 species of conifers in 70 accepted genera, however according to Christenhusz and Byng (2016) their number is 629 species in 69 genera and 06 families. The genus Juniperus L. represented by 75 species is considered to be one of the most diverse genera of gymnosperms distributed from sea level to above tree-line zone (Lakusic and Lakusic, 2011).

India is abode to about 101 species, 9 varieties and 1 form of gymnosperms belonging to 33 genera under 10 families with about 44 species in wild (Srivastava, 2006). A total of 63 species of gymnosperm are reported from western Himalaya (Tewari et al., 2010). Although much less in numbers gymnosperms still constitute

*Author for correspondence; E-mail: gblandleeb@gmail.com dominant element of forests of world in temperate areas of both the northern and southern Hemispheres. They occur in all continents except Antarctica and form outstanding feature of landscape of the Himalaya. The existing gymnosperms belong to six orders: Cycadales, Ginkgoales, Coniferales, Gnetales, Welwitschiales and Ephedrales.

Forests are verily the green gold of the State of Jammu and Kashmir play a vital role in the maintenance of natural balance which is of paramount importance in a mountainous region like ours. Despite their immense ecological and socio-economic values the taxonomy of gymnosperms has been neglected in the Indian subcontinent, especially in the Kashmir Himalaya. Even though Hooker (1888) gave the first taxonomic treatment of gymnosperms of India, but he cited very little material. Since then some local researchers (Dar and Christensan, 2003; Javeid, 1979, 1970; Singh and Kachroo, 1976; Dhar, 1966) attempted to deal with gymnosperm floristics in this region, but the taxonomic intricacy regarding this group in the Kashmir Himalaya still persists. 
It is for these reasons that present investigation was carried out to compile contributions of various taxonomists viz. a viz. diversity in gymnosperms of this region, validate and augment it with extensive field studies so as to present an updated inventory of gymnosperm species in the Kashmir Himalaya.

Study area. Kashmir Himalaya being located at the bio-geographically pivotal position, represents a unique biotic province in the northwestern extreme of the Himalayan range. The region lies between coordinates $32^{\circ} 17^{\prime}$ to $37^{\circ} 20^{\prime}$ north latitude and $73^{\circ} 25^{\prime}$ to $80^{\circ} 30^{\prime}$ east longitude spreading over an area of about 2, 22, $235 \mathrm{~km} 2$ (Hussain, 2001). It comprises mostly of rugged terrain, except for small plains of Jammu and vale of Kashmir, and encompasses four categories of biogeographic biomes: Tundra, Alpine, Temperate and Subtropical (Rodgers and Panwar, 1988). The valley of Kashmir is an oval plain that lies between $32^{\circ} 20^{\prime}$ to $34^{\circ} 50^{\prime}$ north latitude and $73^{\circ} 55^{\prime}$ to $75^{\circ} 35^{\prime}$ east longitude covering an area of about $16,000 \mathrm{sq}$. $\mathrm{km}$. It is formed by a girdling chain of the Himalayan mountains, namely the Pir Panjal range in the south and the great Himalayan range all along the southeast through northeast to the west. The entire territories of the Kashmir valley form two distinct topographic divisions, the mountain ranges and the valley proper. It extends roughly $187 \mathrm{~km}$ in length and about $116 \mathrm{~km}$ in breadth along the latitudes of Srinagar. On an average, the climate of valley is temperate with bixeric regimes, having two dry spells in June and September, and high precipitation during the winter season.

\section{Materials and Methods}

After thorough study of the available herbarium specimens in Kashmir University Herbarium (KASH) and comprehensive literature evaluation from varied sources, different forest habitats in the Kashmir Himalaya were explored for collection of specimens of different gymnosperm species. They were assigned a specific field number and on spot diagnostic characters were noted in the field book. In case of Abies, Picea and Cedrus, where all the leaves (needles) fell down the twigs a few days after direct pressing, the method proposed by page (1979) proved effective. Female cones of Cedrus and Abies, where bract and ovuliferous scales fall, while still on the tree, were collected just prior to dismembering stage and kept air tight in small polythene bags so as to keep them intact. The specimens were identified using the available literature on floristics of this region. Data pertaining to enumeration and distribution of taxa along with altitude (wherever available) has been tabulated.

Taxonomic appraisal. The preliminary work on taxonomy of gymnosperms in India actually commenced from Drury, who in (1869) reported a few gymnosperms from India. Hooker's work (1888) is however, considered to be the first solid step in this direction. Treated the gymnosperms as Gymnospermae and reported 30 species in 16 genera belonging to 3 families (natural orders) from the British India. Out of these, 11 species spread over 5 genera and 2 families have been cited from the Kashmir Himalaya (Table 1). Hooker also recognized six tribes in order Coniferae on the basis of position of ovule, as follows:

A. Ovule erect: I. Cupressinae II. Taxodiaceae III. Taxeae

B. Ovule reversed: I. Podocarpeae II. Araucarieae III. Abietineae

Hooker (1888) and Gamble (1902), each recognized four Juniper species from India. These are as follows:

Juniperus macropoda - Inner drier regions of the Himalaya from Afghanistan to Nepal (1500-4500m).

J. communis - Western Himalaya from Nepal westwards (2000$5000 \mathrm{~m})$.

J. recurva - Himalaya from Afghanistan to Bhutan (3000-4500m).

$\begin{array}{ll}\text { J.pseudosabina } & \text { - Himalaya from } \\ & \text { Afghanistan to Bhutan } \\ & (3000-4500 \mathrm{~m}) .\end{array}$

Brandis (1906) reported 47 species of gymnosperms belonging to 12 genera and 3 families from the British Indian Empire. Out of these, 14 species belonging to 8 genera within 2 families were cited from Kashmir Himalaya (Table 2). Lambert (1933) in his list of trees and shrubs for Kashmir and Jammu forest circles reported 13 species of gymnosperms belonging to 7 genera (Table 3 ).

Raizada and Sahni (1960) have reported 42 species of gymnosperms belonging to 14 genera in 7 families from the Indian sub-continent. Out of these, 13 species belonging to 7 genera in 3 families have been cited 
from the Kashmir Himalaya (Table 4). Raizada and Sahni (1960) have documented 6 species of Junipers from the Himalaya: two species with scaly leaves in the adult stage, viz. Juniperus wallichiana and J. macropoda and other 4 species with acicular adult foliage, namely $J$. coxii, J. recurva, J. squamata and $J$. communis.

Wali and Tiko (1964) have reported 7 species belonging to 6 genera in a single family Coniferae from the Lolab valley in Kashmir. These are as follows:

\section{Coniferae:}

$\begin{array}{lll}\text { Juniperus } & - & \text { J. communis, J. recurva } \\ \text { Taxus } & - & \text { T. baccata } \\ \text { Pinus } & - & \text { P. wallichiana } \\ \text { Cedrus } & - & \text { C. deodara } \\ \text { Picea } & - & \text { P. smithiana } \\ \text { Abies } & - & \text { A. pindrow }\end{array}$

Table 1. Gymnosperm taxa reported from British India (Hooker, 1888)

\begin{tabular}{|c|c|c|c|c|c|}
\hline \multirow{2}{*}{$\begin{array}{l}\text { Name of } \\
\text { family }\end{array}$} & \multicolumn{2}{|c|}{ Genus } & \multicolumn{2}{|r|}{ Species } & \multirow[t]{2}{*}{ Taxa cited from Kashmir Himalaya } \\
\hline & Number & Name & Number & Name & \\
\hline \multirow[t]{8}{*}{ Gnetaceae } & 2 & Ephedra & 3 & E. vulgaris & E. vulgaris (Western Tibet). \\
\hline & & & & $\begin{array}{l}\text { E. pachyclada } \\
\text { E. peduncularis }\end{array}$ & E. pachyclada (Western Himalaya, Western Tibet). \\
\hline & & Gnetum & 6 & G. gnemone & -- \\
\hline & & & & G. neglectum & \\
\hline & & & & G. macrostachyum & \\
\hline & & & & G. scandens & \\
\hline & & & & G. funiculare & \\
\hline & & & & G. macropodum & \\
\hline \multirow[t]{25}{*}{ Coniferae } & 13 & Cupressus & 3 & C. torulosa & C. sempervirens (Northwest India). \\
\hline & & & & C. sempervirens & C. torulosa (Western Himalaya). \\
\hline & & & & C. funebris & \\
\hline & & Juniperus & 4 & J. communis & J. pseudo-sabina (Kashmir to Bhutan). \\
\hline & & & & J. pseudosabina & J. communis (Western Himalaya, Kumaon westwards). \\
\hline & & & & J. recurva & J. macropoda (Western Tibet, 5000 - 14000f). \\
\hline & & & & J. macropoda & \\
\hline & & Cephalotaxus & & C. manii & -- \\
\hline & & & & C. griffithi & \\
\hline & & Taxus & & T. baccata & T. baccata (Temperate Himalaya). \\
\hline & & Dacrydium & & D. elatum & -- \\
\hline & & Podocarpus & & P. latifolius & \\
\hline & & & & P. neriifolius & \\
\hline & & A rothic & & P. cupressine & \\
\hline & & & & & \\
\hline & & Pinus & 5 & P. excelsa & P. excelsa (Temperate Himalaya, 6000-12000f). \\
\hline & & & & P. longifolia & P. longifolia (Indus-Bhutan, 1500-6000f). \\
\hline & & & & P. khasya & P. gerardiana (Dry interior valleys of North-west Himalaya, 5000-12000f). \\
\hline & & & & P. gerardiana & \\
\hline & & & & P. merkusii & \\
\hline & & Cedrus & 1 & C. libani & -- \\
\hline & & Picea & 1 & P. morinda & \\
\hline & & Tsuga & 1 & T. brunoniana & \\
\hline & & Abies & 1 & $\begin{array}{l}\text { A. webbiana } \\
\text { var. webbiana }\end{array}$ & \\
\hline & & Larix & 1 & L. griffithii & \\
\hline \multirow{5}{*}{\multicolumn{2}{|c|}{ Cycadaceae 1}} & Cycas & 5 & C. circinalis & -- \\
\hline & & & & C. rumphii & \\
\hline & & & & C. pectinata & \\
\hline & & & & C. siamensis & \\
\hline & & & & C. beddomei & -- \\
\hline Total $=3$ & 16 & -- & 39 & -- & 11 \\
\hline
\end{tabular}


Dhar (1966) while dealing with distribution of Pinaceae in India has cited 14 indigenous species of gymnosperms belonging to 12 genera and 6 families of order Coniferales. Out of these, 7 species in 4 genera of family Pinaceae have been cited from the Kashmir Himalaya (Table 5).
Dallimore and Jackson (1966) have reported only 5 species of Junipers from Himalaya, viz. J. communis, J. macropoda, J. recurva, J. squamata and J. wallichiana (=J. pseudosabina). It is worth mentioning here that $J$. coxii has been treated as a variety of $J$. recurva.

Table 2. Gymnosperm taxa reported from Kashmir Himalaya (Brandis, 1906)

\begin{tabular}{|c|c|c|c|c|c|}
\hline \multirow{2}{*}{$\begin{array}{l}\text { Name of } \\
\text { family }\end{array}$} & \multicolumn{2}{|c|}{ Genus } & \multicolumn{2}{|r|}{ Species } & \multirow[t]{2}{*}{ Distribution in Kashmir Himalaya } \\
\hline & Number & Name & Number & Name & \\
\hline Gnetaceae & 1 & Ephedra & 3 & $\begin{array}{l}\text { E. gerardiana (E. vulgaris) } \\
\text { E. nebrodensis } \\
\text { E. intermedia }\end{array}$ & $\begin{array}{l}\text { Himalaya: Kuram Valley, Yarkand, Tibet. Baltistan. } \\
\text { Northern Himalaya: Gilgit, Zanskar, Upper Chenab. }\end{array}$ \\
\hline \multirow[t]{7}{*}{ Coniferae } & 13 & Pinus & 2 & $\begin{array}{l}\text { P. excelsa } \\
P . \text { gerardiana }\end{array}$ & $\begin{array}{l}\text { Bhutan to Afghanistan. } \\
\text { Northwest Himalaya: Gilgit, Indus between Astor } \\
\text { and Iskardo, Upper Chenab. }\end{array}$ \\
\hline & & Cedrus & 1 & C. deodara (C. libani var. deodara) & Northwest Himalaya (4000-10000f). \\
\hline & & Abies & 2 & $\begin{array}{l}\text { A. pindrow } \\
\text { A. webbiana }\end{array}$ & $\begin{array}{l}\text { Kurram valley, eastwards to Nepal. } \\
\text { Northwest Himalaya (10000-14000f). }\end{array}$ \\
\hline & & Picea & 1 & P. morinda (Abies smithiana) & $\begin{array}{l}\text { Himalaya: Common from Kashmir to Garhwal and } \\
\text { Gilgit. }\end{array}$ \\
\hline & & Cupressus & 1 & C. sempervirens & Planted in gardens of Northwest India. \\
\hline & & Juniperus & 3 & $\begin{array}{l}J . \text { communis } \\
J . \text { recurva } \\
J . \text { macropoda (J. excelsa) }\end{array}$ & $\begin{array}{l}\text { Northwest Himalaya (5400-14000f). } \\
\text { Kashmir to Bhutan ( } 7500-12000 \mathrm{f}) \text {. } \\
\text { Inner arid ranges and valleys of Northwest Himalaya. }\end{array}$ \\
\hline & & Taxus & 1 & T. baccata subsp. wallichiana & India. \\
\hline
\end{tabular}

Table 3. Gymnosperm taxa reported from Kashmir and Jammu forest circles (Lambert, 1933)

\begin{tabular}{|c|c|c|c|}
\hline \multirow{2}{*}{$\begin{array}{l}\text { Name of } \\
\text { genus }\end{array}$} & \multicolumn{2}{|c|}{ Species } & \multirow[t]{2}{*}{ Distribution in Kashmir Himalaya } \\
\hline & Number & Name & \\
\hline Ephedra & 2 & $\begin{array}{l}\text { E. gerardiana } \\
\text { E. intermedia }\end{array}$ & $\begin{array}{l}\text { Gurez, Jhelum Valley. Kishanganaga, Sind Valley. } \\
\text { Kashmir, Baltistan, Chenab valley, Jammu, Mirpur, Muzaffarabard, Udhampur. }\end{array}$ \\
\hline Pinus & 3 & $\begin{array}{l}\text { P. longifolia } \\
\text { P. gerardiana } \\
\text { P. excelsa }\end{array}$ & $\begin{array}{l}\text { Baltistan, Chenab valley, Jammu, Kamraj, Mirpur, Muzaffarabard, Udhampur. } \\
\text { Mainder, Kashmir. } \\
\text { Jhelum Valley, Gurez, Kamraj, Kishanganaga, Mainder, Muzaffarabad, Sind Valley, Udhampur. }\end{array}$ \\
\hline Picea & 1 & P. smithiana & Gurez, Jhelum Valley. Kishanganaga, Kashmir, Mainder, Muzaffarabard, Sind Valley, Udhampur. \\
\hline Abies & 1 & A. pindrow & Gurez, Jhelum Valley. Kamraj, Kishanganaga, Kashmir, Sind Valley, Udhampur. \\
\hline Cedrus & 1 & C. deodara & $\begin{array}{l}\text { Gurez, Jhelum Valley, Kamraj, Kishanganaga, Kashmir, Mainder, Muzaffarabard, } \\
\text { Sind Valley, Pir Panjal, Udhampur. }\end{array}$ \\
\hline Juniperus & 4 & $\begin{array}{l}\text { J. communis } \\
\text { J. squamata } \\
\text { J. macropoda } \\
\text { J. pseudosabina }\end{array}$ & $\begin{array}{l}\text { Gurez, Jhelum Valley. Kashmir, Mainder, Sind Valley. } \\
\text { Gurez, Jhelum Valley. Kishanganaga, Kashmir. } \\
\text { Mainder, Sind Valley, Gurez, Kishanganaga, Sind Valley, Kashmir. }\end{array}$ \\
\hline Taxus & 1 & T. baccata & $\begin{array}{l}\text { Gurez, Jhelum Valley. Kamraj, Kishanganaga, Kashmir, Mainder, Muzaffarabard, Sind Valley, } \\
\text { Udhampur. }\end{array}$ \\
\hline
\end{tabular}


Gaussen (1968) has reported 7 species of Junipers from the Himalaya, as follows:

\begin{tabular}{|c|c|}
\hline$\underline{\text { Name of species }}$ & $\underline{\text { Distribution }}$ \\
\hline J. pseudosabina & - Throughout the Himalaya. \\
\hline J. wallichiana & $\begin{array}{l}\text { - Indus to Bhutan (2700- } \\
4500 \mathrm{~m}) \text {. }\end{array}$ \\
\hline J. religiosa (J. excelsa) & $\begin{array}{l}\text { - Drier ranges of Northwest } \\
\text { Himalaya from Kashmir to } \\
\text { Nepal (1500-3000m). }\end{array}$ \\
\hline $\begin{array}{l}\text { J. macropoda } \\
(4000 \mathrm{~m}) \text {. }\end{array}$ & - Afghanistan to western Nepal \\
\hline J. squamata & $\begin{array}{l}\text { - Himalaya }(3,000-5,000 \mathrm{~m}) \text { in } \\
\text { Alpine zone. }\end{array}$ \\
\hline J. recurva & $\begin{array}{l}\text { - Eastern Himalaya in } \\
\text { temperate or sub-alpine zone } \\
\text { in Sikkim and Bhutan }(3,000- \\
4000 \mathrm{~m}) \text {; Afghanistan, } \\
\text { Kashmir, Tibet. }\end{array}$ \\
\hline
\end{tabular}

Javeid (1970) has described 11 species of gymnosperms belonging to 10 genera and 5 families from Srinagar Kashmir (Table 6). Stewart (1972) treated gymnosperms as class Gymnospermae and cited 35 species in 14 genera belonging to 5 orders of them from Pakistan and Kashmir. Out of these, 17 species in 7 genera have been recognized from the Kashmir Himalaya (Table 7). Koul and Sarin (1974) studied the vertical distribution of plant communities between 1,000 and $3900 \mathrm{~m}$ altitudes in Bhaderwah hills (western Himalaya) and found a well marked zonation of vegetation from lower to upper elevation. The lower zone (1,600-1,900m) comprises Quericus incana, Q. floribunda and Pinus wallichiana; the intermediate slopes $(2,000-2,600 \mathrm{~m})$ consists of almost pure stands of Cedrus deodara, while locations from 2,000-3,700m are dominated by Abies pindrow forests. The oaks were restricted to drier situations and conifers to moist slopes. Dhar (1975) has reported a healthy, well-grown fertile specimen of a prodigious

Table 4. Gymnosperm taxa reported from Kashmir Himalaya (Raizada and Sahni, 1960)

\begin{tabular}{|c|c|c|c|c|c|}
\hline \multirow{2}{*}{$\begin{array}{l}\text { Name of } \\
\text { family }\end{array}$} & \multicolumn{2}{|c|}{ Genus } & \multicolumn{2}{|c|}{ Species } & \multirow[t]{2}{*}{ Distribution } \\
\hline & Number & Name & Number & Name & \\
\hline \multirow[t]{4}{*}{ Pinaceae } & 4 & Abies & 2 & $\begin{array}{l}\text { A. pindrow } \\
\text { A. spectabilis }\end{array}$ & $\begin{array}{l}\text { Afghanistan to Nepal }(2300-3300 \mathrm{~m}) \text {. } \\
\text { West Pakistan to Bhutan }(3300-4000 \mathrm{~m}) \text {. }\end{array}$ \\
\hline & & Cedrus & 1 & C. deodara & Afghanistan to Garhwal. \\
\hline & & Picea & 1 & P. smithiana & Afghanistan to Kumaon (2150-3200m). \\
\hline & & Pinus & 5 & $\begin{array}{l}\text { P. gerardiana } \\
\text { P. roxburghii } \\
\text { P. wallichiana }\end{array}$ & $\begin{array}{l}\text { From Bashahar westwards to Kashmir. } \\
\text { Afghanistan to Bhutan }(450-2300 \mathrm{~m}) \text {. } \\
\text { All along Himalaya } 1800-3700 \mathrm{~m}) \text {. }\end{array}$ \\
\hline Taxaceae & 1 & Taxus & 1 & T. baccata & All along Himalaya 1800-3700m). \\
\hline \multirow[t]{2}{*}{ Cupressaceae } & 2 & Cupressus & 1 & C. torulosa & West Pakistan and Kashmir. \\
\hline & & Juniperus & 4 & $\begin{array}{l}\text { J. communis } \\
\text { J. macropoda } \\
\text { J. recurva } \\
\text { J. wallichiana }\end{array}$ & $\begin{array}{l}\text { Afghanistan to Kumaon }(1700-4300 \mathrm{~m}) \text {. } \\
\text { Kashmir, }(1500-4300 \mathrm{~m}) \text {. } \\
\text { All along Himalaya from West Pakistan to Bhutan }(2300-4600 \mathrm{~m}) \text {. } \\
\text { Indus Nepal }(3300-4200 \mathrm{~m}) \text {. }\end{array}$ \\
\hline
\end{tabular}

Table 5. Gymnosperm taxa reported from Kashmir Himalaya (Dhar, 1966)

\begin{tabular}{|c|c|c|c|c|c|}
\hline \multirow{2}{*}{$\begin{array}{l}\text { Name of } \\
\text { family }\end{array}$} & \multicolumn{2}{|c|}{ Genus } & \multicolumn{2}{|c|}{ Species } & \multirow[t]{2}{*}{ Distribution } \\
\hline & Number & Name & Number & Name & \\
\hline \multirow[t]{4}{*}{ Pinaceae } & 4 & Pinus & 3 & $\begin{array}{l}\text { P. roxburghii } \\
\text { P. wallichiana } \\
\text { P. gerardiana }\end{array}$ & $\begin{array}{l}\text { Kashmir to Bhutan. } \\
\text { Northwestern Himalaya. } \\
\text { Bashahar to Kashmir. }\end{array}$ \\
\hline & & Cedrus & 1 & C. deodara & North-west Himalaya from Garhwal to Kashmir. \\
\hline & & Picea & 1 & P. smithiana & Western Himalaya from Kashmir to Kumaon. \\
\hline & & Abies & 2 & $\begin{array}{l}\text { A. pindrow } \\
\text { A. spectabilis }\end{array}$ & Western Himalaya from Kashmir to Nepal. Western Himalaya. \\
\hline
\end{tabular}


conifer- Sequoiadendron giganteum growing in the Yarikha Drug Farm, Tangmarg Kashmir.

Mehra (1975) using taxonomic and anatomical tools has tried to resolve the Abies and Juniperus complexes existing in the Himalaya. According to author 4 types of firs are met within the western Himalaya viz. (1) high-level Abies spectabilis (2) high-level hybrid (3) low-level hybrid and (4) low-level $A$. pindrow. Regarding Juniperus complex, the author has concluded that in all there are 9 species of Junipers in the Himalaya, of these 5 are trees and 4 shrubs. Juniperus pseudosabina is a shrub occurring all-along the Himalayan range from west to east. Out of the other 8 species, 4 are met within the western Himalaya and an equal number in the eastern Himalaya. The western Himalayan Junipers are: $J$. communis, J. squamata (both shrubs), J. macropoda and $J$. excelsa var. Farreana (both trees).

Singh and Kachroo (1976) have reported 6 species of gymnosperms in 5 genera belonging to 2 families from Srinagar. These are as follows:

\section{Pinaceae:}

$\begin{array}{ll}\text { Abies } & - \text { A. pindrow } \\ \text { Juniperus } & - \text { J. communis, J. recurva } \\ \text { Picea } & - \text { P. smithiana } \\ \text { Pinus } & - \text { P.griffithii }\end{array}$

Taxaceae:

Taxus - T. wallichiana

Based on extensive survey of Juniperus populations in various parts of the Himalaya and the details of morphological and anatomical characters, Jain (1976) has reported 8 distinct taxa of Juniper from the entire Himalayan range. In the eastern Himalaya 5 taxa are

Table 6. Gymnosperm taxa reported from Kashmir Himalaya (Javeid, 1970)

\begin{tabular}{|c|c|c|c|c|}
\hline \multirow{2}{*}{$\begin{array}{l}\text { Name of } \\
\text { family }\end{array}$} & \multicolumn{2}{|c|}{ Genus } & \multicolumn{2}{|c|}{ Species } \\
\hline & Number & Name & Number & Name \\
\hline Ginkgoaceae & 1 & Ginkgo & 1 & G. biloba \\
\hline \multirow[t]{4}{*}{ Pinaceae } & 4 & Pinus & 2 & $\begin{array}{l}\text { P. wallichiana } \\
\text { P. halepensis }\end{array}$ \\
\hline & & Cedrus & 1 & C. deodara \\
\hline & & Picea & 1 & P. smithiana \\
\hline & & Abies & 2 & A. pindrow \\
\hline \multirow[t]{3}{*}{ Cupressaceae } & 3 & Thuja & 1 & T. orientalis \\
\hline & & Cupressus & 1 & C. arizonica \\
\hline & & Juniperus & 1 & J. communis \\
\hline Taxaceae & 1 & Taxus & 1 & T. wallichiana \\
\hline Ephedraceae & 1 & Ephedra & 1 & E. gerardiana \\
\hline
\end{tabular}

present, 3 (J. wallichiana, J. recurva and J. fargesii) are trees and restricted to the eastern Himalaya, while the other 2 also extend to the western Himalaya. The west Himalayan taxa are also 5 in number: $J$. macropoda and $J$. excelsa being trees, whereas $J$. communis ssp. Nana, J. squamata and J. pseudo-sabina are shrubs.

Dhar (1978) has reported 8 species of gymnosperms from the Kashmir Himalaya. Among these 6 species viz. Pinus wallichiana, P. excelsa, Cedrus deodara, Picea smithiana, Abies pindrow, Taxus baccata are distributed along temperate and subalpine region, while the rest 2 species i.e., Juniperus communis and Juniperus recurva are distributed along subalpine to alpine region. Javeid (1979) has reported 19 species of gymnosperms belonging to 19 genera in 4 orders and 5 families under a single class Gymnospermae from the Kashmir Himalaya. Out of these, 3 species are grown as ornamentals, while the rest occur as wild (Table 8). Lancaster (1980) has reported 6 species of gymnosperms from Kashmir viz. Abies pindrow, Pinus wallichiana, Taxus wallichiana, Picea smithiana, Juniperus communis spp. Montana (nana), and Juniperus macropoda. The specimens of these taxa have been collected from Lidder valley, Gulmarg and Lashpatri, Sonamarg and Vishensar in Sind valley regions of Kashmir. Polunin and Stainton (1984) have reported 22 species of gymnosperms belonging to 11 genera and 5 families from the entire Himalayan region (Table 9). Bhat (1984) has reported 5 species of gymnosperms (Pinus wallichiana, Picea smithiana, Cedrus deodara, Abies pindrow and Juniperus communis) from Gulmarg area. These are distributed along forest slopes from Tangmarg to Khillanmarg.

Mehra (1988) has described 38 species of gymnosperms belonging to 13 genera from India. Out of these, 29 species falling into 11 genera have been treated under conifers and the rest 9 species belonging to 2 genera have been treated under Gnetophytes (Table 10). Conifers are mostly confined to Himalaya especially in northwest and western regions. Pinaceae among conifers has the maximum representation with 14 species in 2 genera. Cephalotaxaceae, Podocarpaceae and Taxaceae are each represented by a single genus with 2 species each in the first two and only one species in last one. Taxodiaceae and Araucariaceae are not represented in wild. Out of total, 15 species of gymnosperms belonging to 7 genera have been reported from the Kashmir Himalaya. Among these, 12 species belonging to 6 genera fall under conifers and the rest 3 species belonging to 1 genus fall under Gnetophytes. 
Sahni (1990) has reported 61 species of gymnosperms belonging to 16 genera in 8 families from the Indian sub-continent. Out of these, 54 species belonging to 15 genera in 8 families have been cited from India; these includes 23 species belonging to 8 genera in 4 families reported from the Kashmir Himalaya (Table 11).

Singh and Kachroo (1994) have reported 7 species of gymnosperms belonging to 6 genera in 3 families from the Pir Panjal range. These are as follows:

\section{Pinaceae:}

Abies - A.pindrow

Cedrus - C. deodara

Pinus - P. wallichiana

\section{Cupressaceae:}

Juniperus - J. communis, J. recurva

Picea - P. smithiana

Taxaceae:

Taxus - T. baccata

Table 7. Gymnosperm taxa reported from Pakistan and Kashmir (Stewart, 1972)

\begin{tabular}{|c|c|c|c|c|c|c|c|}
\hline \multirow{2}{*}{$\begin{array}{l}\text { Name of } \\
\text { order }\end{array}$} & \multicolumn{2}{|c|}{ Family } & \multicolumn{2}{|c|}{ Genus } & \multicolumn{2}{|r|}{ Species } & \multirow[t]{2}{*}{ Taxa cited from Kashmir Himalaya } \\
\hline & Number & Name & Number & Name & Number & Name & \\
\hline \multirow[t]{2}{*}{ Cycadales } & - & - & 2 & Cycas & 2 & $\begin{array}{l}\text { C. revoluta } \\
\text { C. rumphii }\end{array}$ & - \\
\hline & & & & Zamia & 1 & Z. integrifolia & - \\
\hline Ginkgoales & - & - & 1 & Ginkgo & 1 & G. biloba & - \\
\hline Ephedrales & - & - & 1 & Ephedra & 9 & $\begin{array}{l}\text { E. ciliata } \\
\text { E. gerardiana } \\
\text { E. intermedia } \\
\text { var. gluaca } \\
\text { E. intermedia } \\
\text { var. tibetica } \\
\text { E. pachyclada } \\
\text { E. procera } \\
\text { E. przewalskii } \\
\text { E. regeliana } \\
\text { E. sarcocarpa } \\
\text { E. monosperma. }\end{array}$ & $\begin{array}{l}\text { E. gerardiana } \\
\text { (Kashmir, } 5500-17000 f) \text {. } \\
\text { E. intermedia } \text { var. tibetica (Kashmir). } \\
\text { E. pachyclada (W. Tibet, probably Ladakh). } \\
\text { E. procera (Kishtwar). } \\
\text { E. przewalskii (Nanga Parbat). } \\
\text { E. regeliana (Ladakh). }\end{array}$ \\
\hline \multirow[t]{10}{*}{ Coniferales } & 4 & Pinaceae & 4 & Abies & 2 & A. pindrow & A. pindrow \\
\hline & & & & & & $\begin{array}{l}\text { A. spectabilis } \\
\text { A. spectabilis }\end{array}$ & $\begin{array}{l}\text { (Afghanistan to Kumaon, 7-10000f). } \\
\text { (Afghanistan to Bhutan, 8-13000f). }\end{array}$ \\
\hline & & & & Cedrus & 1 & C. deodara & C. deodara (Kashmir, 4-10000f). \\
\hline & & & & Picea & 1 & P. smithiana & P. smithiana (Kashmir, 6-11000f). \\
\hline & & & & Pinus & 4 & $\begin{array}{l}\text { P. gerardiana } \\
\text { P. roxburghii } \\
\text { P. wallichiana } \\
\text { P. halepensis }\end{array}$ & $\begin{array}{l}\text { P. gerardiana (Kishtwar). } \\
\text { P. roxburghii (Afghanistan to Bhutan 1500-6000f). }\end{array}$ \\
\hline & & Taxodiaceae & 1 & Taxodium & 1 & T. mucronatum & - \\
\hline & & Araucariaceae & 1 & Araucaria & 1 & A. cookie & - \\
\hline & & Cupressaceae & 3 & Cupressus & 5 & $\begin{array}{l}\text { C. funebris } \\
\text { C. lusitanica } \\
\text { C. macrocarpa } \\
\text { C. sempervirens } \\
\text { C. torulosa }\end{array}$ & - \\
\hline & & & & Juniperus & 5 & $\begin{array}{l}\text { J. communis } \\
\text { var. saxatilis } \\
\text { J. excelsa } \\
\text { J. squamata } \\
\text { J. turkistanica } \\
\text { J. wallichiana }\end{array}$ & $\begin{array}{l}\text { J. communis var. saxatilis (Dras, Ladakh, } \\
\text { Kashmir 8-14000f). } \\
\text { J. squamata (Kashmir 8-14000f). } \\
\text { J. turkistanica (Nanga Parbar). } \\
\text { J. wallichiana (Kishtwar, chiefly east of Kashmir). }\end{array}$ \\
\hline & & & & Thuja & 1 & T. orientalis & - \\
\hline Taxales & - & - & 1 & Taxus & 1 & T. wallichiana & T. wallichiana (Poonch, Kashmir 6-11000f). \\
\hline Total $=5$ & 4 & - & 14 & - & 35 & - & 17 \\
\hline
\end{tabular}


Ara et al. (1995) have reported 295 indigenous and exotic species in 12 genera under 60 families from the Kashmir Valley. Out of these, 18 species in 11 genera under 5 families belong to gymnosperms; 15 species in 10 genera under 5 families being trees and the remaining 3 species in one genus being shrubs. Further out of these gymnosperms, 9 species in 6 genera and 4 families are exotic, while the remaining 9 species in 7 genera and 3 families are indigenous to Kashmir (Table 12). Dar et al. (2002) have reported 26 species (both wild as well as cultivated) of gymnosperms belonging to 12 genera and 6 families from the Kashmir valley. These are as follows:

\section{Wild growing gymnosperms in Kashmir}

\section{Cupressaceae:}

$\begin{array}{ll}\text { Cupressus } & \text { - C. torulosa } \\ \text { Juniperus } & \text { - J. communis, J. semiglobosa, } \\ & \text { J. squamata }\end{array}$

\section{Ephedraceae:}

$$
\text { Ephedra - E. gerardiana }
$$

Pinaceae:

$\begin{array}{ll}\text { Pinus } & \text { - P. wallichiana, } \text { P. roxburghii } \\ \text { Abies } & \text { - A. pindrow, A. spectabilis } \\ \text { Cedrus } & \text { - C. deodara } \\ \text { Picea } & \text { - P. smithiana }\end{array}$

Taxaceae:
Taxus
- T. wallichiana

$\underline{\text { Exotic gymnosperms grown as ornamentals }}$

\section{in Kashmir}

\section{Cupressaceae:}

Cupressus - C.arizonica, C. cashmeriana, C. corneyana, C. glabra, C. guadalupensis, C. sempervirens

Juniperus - J.chinensis

Thuja $\quad-$ T. orientalis

Ginkgoaceae:

Ginkgo

- G. biloba

Pinaceae:

Pinus

- P. canariensis, P. halepensis, P. radiata

Taxodiaceae:

$$
\begin{array}{ll}
\text { Cyptomeria } & - \text { C. japonica } \\
\text { Sequoiadendron } & - \text { S. giganteum }
\end{array}
$$

Khan (2002) has reported 5 species of gymnosperms in 5 genera belonging to 3 families from Bijhama (Uri) and its adjacent areas in Kashmir as below:

\begin{tabular}{|c|c|c|c|c|c|c|c|}
\hline \multirow{2}{*}{$\begin{array}{l}\text { Name of } \\
\text { order }\end{array}$} & \multicolumn{2}{|c|}{ Family } & \multicolumn{2}{|c|}{ Genus } & \multicolumn{2}{|r|}{ Species } & \multirow[t]{2}{*}{ Distribution in the Kashmir Himalaya } \\
\hline & Number & Name & Number & Name & Number & Name & \\
\hline Ginkgoales & - & - & 1 & Ginkgo & 1 & G. biloba & Lanlmandi garden (cultivated). \\
\hline Ephedrales & - & - & 1 & Ephedra & 3 & $\begin{array}{l}\text { E. gerardiana } \\
\text { E. vulgaris } \\
\text { E. intermedia }\end{array}$ & $\begin{array}{l}\text { Gurez, Jhelum and Sind valley. Srinagar, } \\
\text { Ldakh, Zanskar. Gurez. }\end{array}$ \\
\hline \multirow[t]{7}{*}{ Coniferales } & 2 & Pinaceae & 4 & Pinus & 4 & $\begin{array}{l}P . \text { wallichiana } \\
P . \text { roxburghii } \\
P . \text { gerardiana } \\
P . \text { halepensis }\end{array}$ & $\begin{array}{l}\text { Gurez, Jhelum, Lolab and Sind valley, } \\
\text { Gulmarg, Pahalgam. } \\
\text { Chenab Valley, Shankarachaya Hill (planted). } \\
\text { Chenab Valley. Shankaracharya (planted). }\end{array}$ \\
\hline & & & & Picea & 1 & P. smithiana & Gurez, Jhelum, Lolab and Sind valley. \\
\hline & & & & Abies & 1 & $\begin{array}{l}\text { A. pindrow } \\
\text { A. spectabilis }\end{array}$ & $\begin{array}{l}\text { Gurez, Jhelum, Lolab and Sind valley. } \\
\text { Common in eastern Himalaya and also reported } \\
\text { from western Himalaya. }\end{array}$ \\
\hline & & & & Cedrus & 1 & C. deodara & Gurez, Jhelum, Lolab and Sind valley. \\
\hline & & Cupressaceae & 2 & Cupressus & 1 & C. torulosa & Srinagar (planted). \\
\hline & & & & Juniperus & 3 & $\begin{array}{l}\text { J. communis } \\
\text { J. squamata } \\
\text { J. wallichiana }\end{array}$ & $\begin{array}{l}\text { Gurez, Drass, Jhelum, Lolab and Sind valley. } \\
\text { Common and often with J. communis above } \\
\text { the tree line. Keran, Kishtwar. }\end{array}$ \\
\hline & & & & Thuja & 1 & T. orientalis & Kashmir Valley (planted). \\
\hline Taxales & 1 & Taxaceae & 1 & Taxus & 2 & $\begin{array}{l}\text { T. wallichiana } \\
\text { T. baccata subsp. } \\
\text { wallichiana }\end{array}$ & Gurez, Jhelum, Lolab and Sind valley. \\
\hline
\end{tabular}

$\begin{array}{ll}\text { Pinaceae: } & \\ \text { Pinus } & - \text { P. wallichiana } \\ \text { Cedrus } & - \text { C. deodara } \\ \text { Abies } & - \text { A. pindrow } \\ \text { Taxaceae: } & \\ \text { Taxus } & - \text { T. baccata } \\ \text { Ephedraceae: } & \\ \text { Ephedra } & - \text { E. gerardiana }\end{array}$

Table 8. Gymnosperm taxa reported from Kashmir Himalaya (Javeid, 1979) 
Table 9. Gymnospermous taxa reported from Kashmir Himalaya (Polunin and Stainton, 1984)

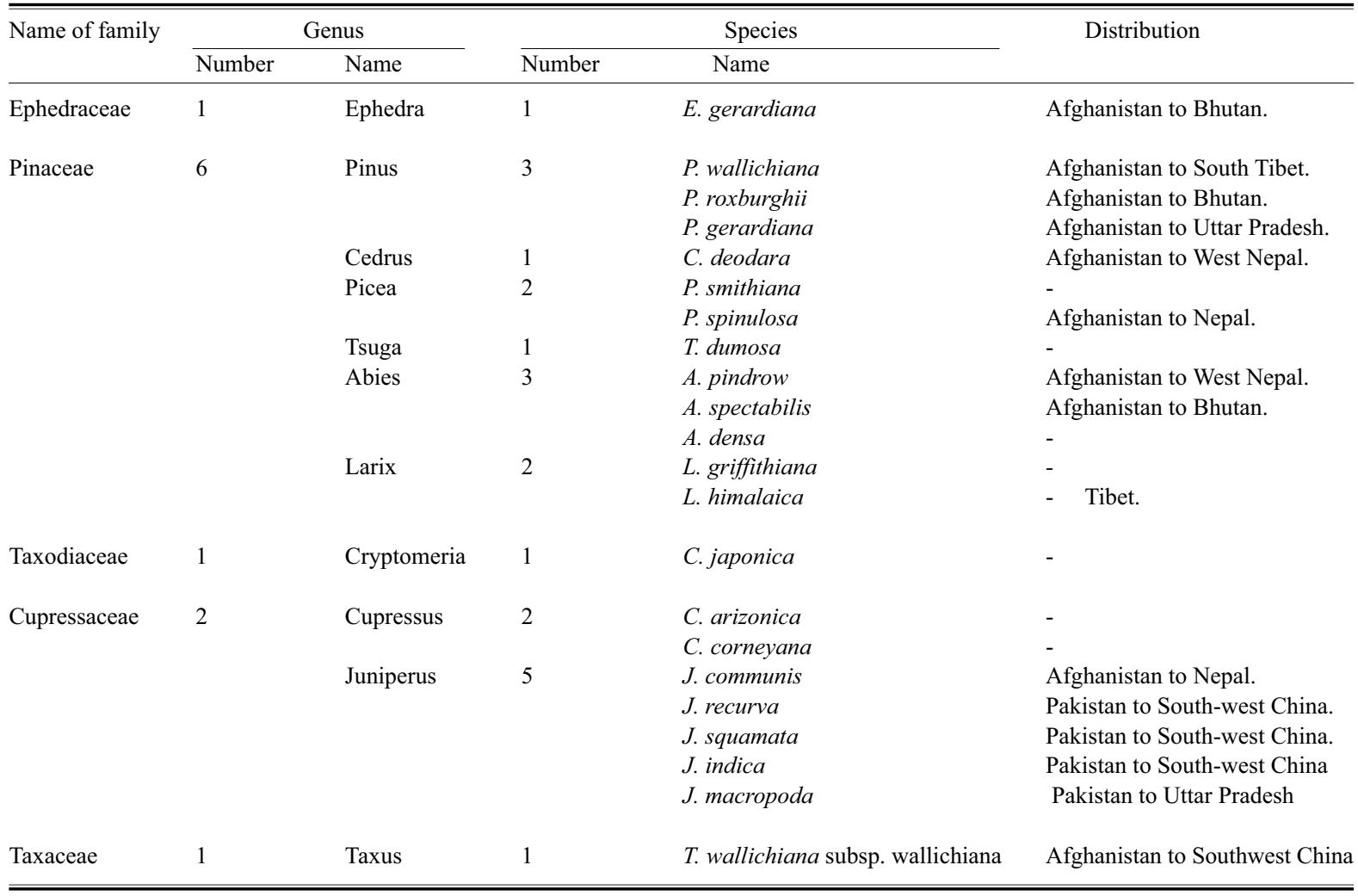

Table 10. Gymnospermous taxa reported from Kashmir Himalaya (Mehra, 1988)

\begin{tabular}{|c|c|c|c|c|c|c|c|c|}
\hline \multirow{2}{*}{$\begin{array}{l}\text { Name of } \\
\text { order }\end{array}$} & \multicolumn{2}{|c|}{ Family } & \multicolumn{2}{|c|}{ Genus } & \multicolumn{2}{|r|}{ Species } & \multirow{2}{*}{$\begin{array}{l}\text { Chromo- } \\
\text { some no. }\end{array}$} & \multirow[t]{2}{*}{ Distribution } \\
\hline & Number & Name & Number & Name & Number & Name & & \\
\hline \multirow[t]{11}{*}{ Coniferales } & 3 & Pinaceae & 4 & Pinus & 3 & P. gerardiana & $2 n=24$ & Inner ranges of Northwest Himalaya $(1100-3300 \mathrm{~m})$. \\
\hline & & & & & & P. roxburghii & $\begin{array}{l}2 \mathrm{n}=24 \\
\mathrm{n}=12\end{array}$ & \\
\hline & & & & & & P. griffithii & $\begin{array}{l}2 \mathrm{n}=24 \\
\mathrm{n}=12\end{array}$ & forests $(200-3000 \mathrm{~m})$ \\
\hline & & & & Cedrus & 1 & C. deodara & $\begin{array}{l}2 n=24 \\
n=12\end{array}$ & $\begin{array}{l}\text { Throughout western Himalaya (1300- } 3200 \mathrm{~m}) \text {, } \\
\text { extending from Afghanistan to Garwhal. }\end{array}$ \\
\hline & & & & Picea & 1 & P. smithiana & $2 n=24$ & Western Himalaya, Nepal to Afghanistan. \\
\hline & & & & Abies & 2 & $\begin{array}{l}\text { A. pindrow } \\
\text { A. spectabilis }\end{array}$ & $\begin{array}{l}2 \mathrm{n}=24 \\
\mathrm{n}=12\end{array}$ & $\begin{array}{l}\text { Western Himalaya, Nepal to Afghanistan } \\
(2400-2700 \mathrm{~m}) \text {. Inner west Himalayan ranges at } \\
\text { higher elevations than that of A. pindrow. }\end{array}$ \\
\hline & & Cupressaceae & 1 & Juniperus & 4 & J. macropoda & $2 n=22$ & Western Himalaya, Sonamarg. \\
\hline & & & & & & J. communis & $2 n=22$ & Western Himalaya, Baltal. \\
\hline & & & & & & J. pseudo-sabina & $2 n=22$ & Western Himalaya, from Kashmir (Baltal) to \\
\hline & & & & & & J. squamata & & Kumoan. Western Himalaya. \\
\hline & & Taxaceae & 1 & Taxus & 1 & T. wallichiana & $\mathrm{n}=12$ & Himalaya $(2000-3000 \mathrm{~m})$, Afghanistan to Bhutan. \\
\hline \multirow[t]{5}{*}{ Gnetophytes } & & Ephedraceae & 1 & Ephedra & 3 & E. intermedia & $\mathrm{n}=14$ & Kashmir. \\
\hline & & & & & & var. tibetica & $2 \mathrm{n}=28$ & \\
\hline & & & & & & E. gerardiana & $\mathrm{n}=14$ & Kashmir. \\
\hline & & & & & & var. wallichii & $\mathrm{n}=14$ & \\
\hline & & & & & & E. saxatilis & $2 n=22$ & Zanaskar, South Tibet. \\
\hline
\end{tabular}


Khanday (2002) has reported 3 species of gymnosperms belonging to 3 genera and 2 families from LowerMundah and its adjacent area in Kashmir as below:

\section{Pinaceae:}
Abies
- A. pindrow
Pinus
- P. wallichiana

Taxaceae:
Taxus
- T. wallichiana

Khuroo (2003) has documented 5 species of gymnosperms belonging to 5 genera in 2 families from Langate (Kupwara) as below:

\section{Pinaceae: \\ Pinus - P. wallichiana \\ Cedrus $\quad-$ C. deodara \\ Abies - A. pindrow \\ Picea - P. smithiana \\ Taxaceae:
Taxus
- T. wallichiana

Dar (2004) has cited a total of 20 species of gymnosperms belonging to 12 genera in 6 families from the Kashmir valley. Of these, 9 species in 7 genera ad 5 families occur in cultivation only (Table 13). The coni- fers, with 16 species in 9 genera and 3 families form the most dominant group. Among families, Pinaceae with 7 species in 4 genera is highest represented, while as Ginkgoaceae with 1 species is least represented.

Dar and Dar (2005) described gymnosperm specie viz. Taxodium distichum from the Kashmir Himalaya. Dar and Dar (2006) reported 16 species spread over 9 genera in 3 families of conifers from Kashmir Himalaya. They stated that family Pinaceae is dominant with 7 species and Taxodiaceae is represented by 2 species only. Further, 7 species in 5 genera have been reported to exist in cultivation. Dar and Dar (2011) updated information on Sequoiadendron giganteum growing in Tangmarg area of Kashmir.

Singh et al. (2018) documented Juniperus chinensis from Gurez valley in the innermost northern part of Kashmir Himalaya. Their findings suggest an extension of known geographic distribution of this species from central and southeast Asia to south Asia hence strongly supporting a relationship between northern Himalayan range of India and southern hill ranges of China.

Table 11. Gymnosperm taxa reported from Kashmir Himalaya (Sahni, 1990)

\begin{tabular}{|c|c|c|c|c|c|}
\hline \multirow{2}{*}{$\begin{array}{l}\text { Name of } \\
\text { family }\end{array}$} & \multicolumn{2}{|c|}{ Genus } & \multicolumn{2}{|c|}{ Species } & \multirow[t]{2}{*}{ Distribution } \\
\hline & Number & Name & Number & Name & \\
\hline Taxaceae & 1 & Taxus & 1 & T. baccata & Himalaya: Pakistan to Arunachal Pradesh (1800-3700m). \\
\hline Pinaceae & 4 & $\begin{array}{l}\text { Pinus } \\
\text { Cedrus } \\
\text { Picea } \\
\text { Abies }\end{array}$ & $\begin{array}{l}1 \\
1 \\
2\end{array}$ & $\begin{array}{l}\text { P. wallichiana } \\
\text { P. gerardiana } \\
\text { P. roxburghii } \\
\text { C. deodara } \\
\text { P. smithiana } \\
\text { A. pindrow } \\
\text { A. spectabilis }\end{array}$ & $\begin{array}{l}\text { Himalaya: Pakistan to Arunachal Pradesh }(1800-3700 \mathrm{~m}) \text {. } \\
\text { Bashahar westwards to Kashmir Chitral. } \\
\text { Himalaya: Pakistan to Arunachal Pradesh (450-2300m). } \\
\text { Afghanistan, Kashmir. } \\
\text { Western Himalaya from Afghanistan to Kumaon }(2150-3200 \mathrm{~m}) \text {. } \\
\text { Western Himalaya to Nepal (2300-3300m). } \\
\text { Himalaya: Pakistan to Arunachal Pradesh, Tibet, commonly } \\
\text { at (3300-4000m). }\end{array}$ \\
\hline Cupressaceae & 2 & Juniperus & 6 & $\begin{array}{l}\text { J. polycarpos } \\
\text { J. recurva } \\
\text { J. communis } \\
\text { J. squamata } \\
\text { J. indica } \\
\text { J. turkistanica } \\
\text { C. corneyana } \\
\text { C. cashmeriana }\end{array}$ & $\begin{array}{l}\text { Kashmir, western Tibet (2500-4300m). } \\
\text { Himalaya: inner valleys to Arunachal Pradesh. } \\
\text { Kumaon westwards to Afghanistan. } \\
\text { Afghanistan, Himalaya. } \\
\text { Northeast Burma. } \\
\text { Himalaya: Indus to Sikkim, Bhutan Naga Parbat. } \\
\text { Tibet. } \\
\text { Unknown in wild, Ladakh (?). }\end{array}$ \\
\hline Gnetaceae & 1 & Ephedra & $7+3$ var & $\begin{array}{l}\text { E. przewalskii } \\
\text { E. pachyclada } \\
\text { E. regeliana } \\
\text { E. gerardiana } \\
\text { E. saxatilis } \\
\text { var. sikkimensis } \\
\text { E. nebrodensis } \\
\text { var. procera } \\
\text { E. intermedia } \\
\text { var. tibetica }\end{array}$ & $\begin{array}{l}\text { Nanga Parbat, Ladakh } \\
\text { Chitiral, Kurram valley. } \\
\text { Karakorum, Ladakh. } \\
\text { Karakorum, Chitral, Gilgit, Baltistan, Kashmir, Ladakh, Zanskar. } \\
\text { Tibet. } \\
\text { Kashmir. } \\
\text { Ladakh. }\end{array}$ \\
\hline
\end{tabular}




\section{Results and Discussion}

In present study through examination of herbarium specimens, literature investigation and extensive field surveys a total of 25 species of gymnosperms belonging to 13 genera, 6 families and 4 orders were documented from the Kashmir Himalaya (Table 16). Out of these, 11 species in 7 genera, falling within 4 families and 3 orders occur in wild (Table 14). The conifers with 9 species in 5 genera and 2 families form the most dominant group. Among families Pinaceae with 6 species in 4 genera is highest represented while Taxaceae with 1 species is least represented. It has been found that over the years several species of gymnosperms have been introduced and cultivated in gardens, parks, bare rocky

Table 12. Gymnosperm taxa reported from Kashmir Himalaya (Ara et al., 1995)

\begin{tabular}{|c|c|c|c|c|c|}
\hline \multirow{2}{*}{$\begin{array}{l}\text { Name of } \\
\text { family }\end{array}$} & \multicolumn{2}{|r|}{ Genus } & \multicolumn{2}{|r|}{ Species } & \multirow[t]{2}{*}{ Distribution in Kashmir Himalaya } \\
\hline & Number & Name & Number & Name & \\
\hline Ginkgoaceae & 1 & Ginkgo & 1 & G. biloba & Lalmandi. \\
\hline \multirow[t]{7}{*}{ Pinaceae } & \multirow[t]{7}{*}{3} & \multirow[t]{4}{*}{ Pinus } & \multirow[t]{4}{*}{4} & P. canariensis & Shankaracharya. \\
\hline & & & & P. roxburghii & Uri, University Campus. \\
\hline & & & & P. halepensis & Shankaracharaya park, Bandipora, University \\
\hline & & & & P. radiata & Botanical Garden, Gulmarg. Shankaracharya. \\
\hline & & Cedrus & 1 & C. deodara & On lower altitudes in almost all forests, Chitarnar. \\
\hline & & Picea & 2 & $\begin{array}{l}\text { P. smithiana } \\
\text { P. spinulosa }\end{array}$ & Afghanistan to Nepal \\
\hline & & Abies & 1 & A. pindrow & All forest divisions, Yusmarg Dachigam, Tangmarg, Aharbal. \\
\hline \multirow[t]{2}{*}{ Taxodiaceae } & \multirow[t]{2}{*}{2} & Cryptomeria & 1 & C. japonica & University Botanical Garden, Shankaracharya. \\
\hline & & Sequoiadendron & 1 & S. giganteum & One old tree in Drug Research Farm Tangmarg. \\
\hline \multirow[t]{6}{*}{ Cupressaceae } & \multirow[t]{6}{*}{2} & Cupressus & 3 & $\begin{array}{l}\text { C. arizonica } \\
\text { C. sempervirens }\end{array}$ & $\begin{array}{l}\text { Parks and Gardens, University Campus. Parks and Gardens, } \\
\text { University Campus. Generally growing between }\end{array}$ \\
\hline & & \multirow{4}{*}{ Juniperus } & & C. torulosa & 2000-3000m, Chitarnar. \\
\hline & & & \multirow[t]{3}{*}{3} & J. communis & Zaberwan, Harwan, \\
\hline & & & & J. squamata & Parimahal, Gadsar, Wakulwan. \\
\hline & & & & J. wallichiana & Common above tree line, Gadsar. Gadsar, Apharwat. \\
\hline & & Thuja & 1 & T. orientalis & Gardens, Parks, Srinagar, Bandipora. \\
\hline Taxaceae & 1 & Taxus & 1 & T. wallichiana & Zaberwan, Dachigam. \\
\hline
\end{tabular}

Table 13. List of Gymnosperm taxa reported from Kashmir Himalaya (Dar, 2004)

\begin{tabular}{|c|c|c|c|c|c|}
\hline Name of order & Name of family & Name of genus & Name of species & Wild growing & Cultivated \\
\hline & & Pinus & P. wallichiana & + & - \\
\hline & & & P. roxburghii & + & - \\
\hline & & & P. halepensis & - & + \\
\hline & & Picea & P. smithiana & + & - \\
\hline & & Cedrus & C. deodara & + & - \\
\hline & & Abies & A. spectabilis & + & - \\
\hline & & & A. pindrow & + & - \\
\hline & & Cryptomeria & C. japonica & - & + \\
\hline & & Sequoiadendron & S. giganteum & - & Single tree growing in Yarikhah Drug farm \\
\hline & & Cupressus & C. torulosa & - & + \\
\hline & & & C. cashmeriana & - & + \\
\hline & & & C. sempervirens & - & + \\
\hline & & Juniperus & J. communis & + & - \\
\hline & & & J. squamata & + & - \\
\hline & & & J. semiglobosa & + & - \\
\hline \multirow{3}{*}{ Taxales } & & Thuja & T. orientalis & - & - \\
\hline & Taxaceae & Taxus & T. wallichiana & + & Single shrub growing in Botanical garden \\
\hline & & & T. baccata & - & Kashmir University \\
\hline Ephedrales & Ephedraceae & Ephedra & E. gerardiana & + & - \\
\hline Ginkgoales & Ginkgaoceae & Ginkgo & G. biloba & - & + \\
\hline Total $=4$ & 6 & 12 & 20 & 11 & 9 \\
\hline
\end{tabular}


slopes and road sides in the State. Out of the total gymnosperms in our State, 14 species in 8 genera and 4 families and 2 orders occur in cultivation only (Table 15). Out of these, order Coniferales represents the dominant proportion with 13 species in 7 genera and 3 families while Ginkgoales is represented by only 1 species. Family Cupressaceae is most dominant with 9 species in 3 genera while as Ginkgoaceae is least represented (Table 15).

There is considerable difference of opinion as to whether there are one, two or more species of Himalayan silver firs. According to Troup (1921) the specific distinction in the Himalayan Silver fir is controversial in spite of the fact that two forms (A. pindrow Royle and A. spectablis Spach.) were raised true to seed. Turrill (1937) forwarded an explanation that it might be due to earlier evolutionary conditions from which Abies alba separated northwards and Abies cephalonica southwards through loss of different genes. Turrill's suggestion does not appear to be likely in the case of Abies spectabilis and Abies pindrow, as it involves the supposition that a new species is being evolved in more or less isolated locality. As per Brandis (1921) the low-level fir changes to high level species on ascending to higher ranges. Elwas and Henry (1906-1913) treated $A$. spectabilis Spach. as a mere variety of $A$. pindrow (A. pindrow var brevifolia).

Parker (1940) stated that the two species viz. A. pindrow and $A$. spectablis hybridize rather freely and that, in consequence, it is not always possible to make a sharp distinction between them. It seems likely that before the ice age there were two distinct Silver firs in the Northwest Himalaya and that during ice age they were forced to migrate. If change in climate was sufficiently rapid, one species might have invaded the zone of other and hybridization would have resulted in a mixed population with perhaps more or less complete submergence locally of one or the other species. As per author what is now occurring may be separation of the hybrid population into two species similar to original ones. The suspected hybrids can be recognized by upcurved tips of branches and trees with this character usually also show the hairy shoots of $A$. spectabilis, but they do not always do so. Parker further states that at some places there appears to be a polymorphic population showing the combination of these characters and this appears to be comparable with the intergrading of A. alba and A. cephalonia in Europe. This has been suggested to be due to hybridization. Abies densa Griff. which is treated as a separate species, is considered by
Table 14. Gymnosperms growing as wild in Kashmir Himalaya

\begin{tabular}{|c|c|c|c|c|}
\hline $\begin{array}{l}\text { Name of } \\
\text { order }\end{array}$ & $\begin{array}{l}\text { Name of } \\
\text { family }\end{array}$ & $\begin{array}{l}\text { Name of } \\
\text { genus }\end{array}$ & $\begin{array}{l}\text { No. of } \\
\text { species }\end{array}$ & $\begin{array}{l}\text { Name of } \\
\text { species }\end{array}$ \\
\hline \multirow[t]{5}{*}{ Coniferales } & Pinaceae & Pinus & 2 & $\begin{array}{l}\text { P. wallichiana } \\
P \text {. roxburghii }\end{array}$ \\
\hline & & Cedrus & 1 & C. deodara \\
\hline & & Picea & 1 & P. smithiana \\
\hline & & Abies & 2 & $\begin{array}{l}\text { A. pindrow } \\
\text { A. spectabilis }\end{array}$ \\
\hline & Cupressaceae & Juniperus & 3 & $\begin{array}{l}\text { J. cummunis } \\
\text { J. squamata } \\
\text { J. semiglobosa }\end{array}$ \\
\hline Taxales & Taxaceae & Taxus & 1 & T. wallichiana \\
\hline Ephedrales & Ephedraceae & Ephedra & 1 & E. gerardiana \\
\hline Total $=3$ & 4 & 7 & 11 & \\
\hline
\end{tabular}

Table 15. Gymnosperms existing in cultivation in Kashmir Himalaya

\begin{tabular}{|c|c|c|c|c|}
\hline $\begin{array}{l}\text { Name of } \\
\text { order }\end{array}$ & $\begin{array}{l}\text { Name of } \\
\text { family }\end{array}$ & $\begin{array}{l}\text { Name of } \\
\text { genus }\end{array}$ & $\begin{array}{l}\text { No. of } \\
\text { species }\end{array}$ & $\begin{array}{l}\text { Name of } \\
\text { species }\end{array}$ \\
\hline \multirow[t]{7}{*}{ Coniferales } & Pinaceae & Pinus & 1 & P. halepensis \\
\hline & Cupressaceae & Cupressus & 6 & $\begin{array}{l}\text { C. torulosa } \\
\text { C. cashmeriana } \\
\text { C. guadalpensis } \\
\text { C. gigantea } \\
\text { C. sempervirens } \\
\text { C. arizonica }\end{array}$ \\
\hline & & Juniperus & 2 & $\begin{array}{l}\text { J. chinensis } \\
\text { J. horizontalis }\end{array}$ \\
\hline & & Thuja & 1 & T. occidentalis \\
\hline & Taxodiaceae & Cryptomeria & 1 & C. japonica \\
\hline & & $\begin{array}{l}\text { Sequoia- } \\
\text { dendron }\end{array}$ & 1 & S. giganteum \\
\hline & & Taxodium & 1 & T. distichum \\
\hline Ginkgoales & Ginkgoaceae & Ginkgo & 1 & G. biloba \\
\hline Total $=2$ & 4 & 8 & 14 & \\
\hline
\end{tabular}

Table 16. Summary of gymnosperm flora of Kashmir Himalaya

\begin{tabular}{lllllll}
\hline \hline $\begin{array}{l}\text { Name of } \\
\text { family }\end{array}$ & $\begin{array}{l}\text { Total } \\
\text { number } \\
\text { of } \\
\text { genera }\end{array}$ & $\begin{array}{l}\text { No. of } \\
\text { genera }\end{array}$ & $\begin{array}{l}\text { No. of } \\
\text { genera } \\
\text { in culti- } \\
\text { vation }\end{array}$ & $\begin{array}{l}\text { Total } \\
\text { no. of } \\
\text { species }\end{array}$ & $\begin{array}{l}\text { No. of } \\
\text { species } \\
\text { existing } \\
\text { in wild }\end{array}$ & $\begin{array}{l}\text { No. of } \\
\text { species } \\
\text { existing in } \\
\text { cultivation }\end{array}$ \\
\hline Pinaceae & 4 & 4 & 1 & 7 & 6 & 1 \\
Cupressaceae & 3 & 1 & 3 & 12 & 3 & 9 \\
Taxodiaceae & 3 & 0 & 3 & 3 & 0 & 3 \\
Taxaceae & 1 & 1 & 0 & 1 & 1 & 0 \\
Ephedraceae & 1 & 1 & 0 & 1 & 1 & 0 \\
Ginkgoaceae & 1 & 0 & 1 & 1 & 0 & 1 \\
Total=06 & 13 & 7 & 8 & 25 & 11 & 14 \\
\hline \hline
\end{tabular}


Dallimore and Jackson (1948) as a synonym of Abies spectabilis Spach. but Raizada and Sahni (1960) on the basis of their study of herbarium material are inclined to regard them as two distinct species.

Rao (1953) stated that hybridisation between $A$. spectabilis and A. pindrow in going on even today, because the zonal difference is narrow and Abies pollen is winddispersed. He argued that Turrill's idea corresponds to the concept of the cline (topocline, ecoline) but his postulate, 'loss of different genes' seems uncalled for. What he probably means is adapted mutations for a northern or a southern situation which after natural selection culminated in the divergence of two species. Yet these two species are compatible in hybridization, hence the intergrading forms. Parker wrongly interpret Turrill when he says, 'it involves the supposition that a new species is being evolved in a number of more or less isolated localities". Turill does not refer to present day divergence and species promotion but to an 'earlier evolutionary conditions'. If Parker is correct in doubting whether A. spectabilis and A. pindrow are two different species at all, then the altitudinal clinal concept will hold good, the two species being considered as only two clinal races which are quite compatible in hybridity. He further states that Parker's speculation that there were two distinct species before the ice age which hybridized under ice age conditions and that subsequent hybridizations is going on till today seems quite unnecessary. The hybridizations are going on today because the zonal difference is narrow and the Abies pollen is winddispersed. This question might be solved by raising self pollinated progeny of suspected hybrids and studying the segregation, if any.

Also, a lot of confusion exists regarding the Juniperus sp. occurring in the Kashmir Himalaya. Hooker (1888), Gamble (1902) and Parker (1924) recognized two species of Juniperus with scaly leaves occurring in the Himalaya viz., J. pseudosabina and J. macropoda. Hooker regarded $J$. wallichiana as synonymous of J. pseudosabina. However, Brandis (1874) recognized $J$. pseudosabina and $J$. wallichiana as separate species. These authors are of the view that Juniperus wallichiana is an evergreen tree attaining a height of $18 \mathrm{~m}$ in Sikkim, but is a gregarious shrub in north-west Himalaya. Dallimore and Jackson (1966) hold the view that $J$. pseudosabina does not occur in India and the species that has been reported as occurring under this name is $J$. wallichiana. They have treated Juniperus coxii as a variety of $J$. recurva. However, none of the authors gave satisfactory criteria for delimitation of these two species.

\section{Conclusion}

In Abies complex, besides its two-parent species $A$. pindrow and $A$. spectabilis there exist swarms of hybrids between these two species. These hybrids show various degrees of intermediacy in characters, such as bark, leaves (arrangement, apex notching, margin recurving, groove prominence), cone characteristic (axis length, thickness, swollen or pointed tips). In case of Juniperus complex, it has been found that J. recurva reported by previous workers (Sahni, 1990; Singh and Kachroo, 1976; Gaussen, 1968; Gamble, 1902; Hooker, 1888) from our area is actually Juniperus squamata. Furthermore, J. macropoda reported from northern Himalaya under various names (e.g $J$. excelsa, $J$. polycarpos) by various workers (Sahni, 1990; Raizada and Sahni, 1960; Lambert, 1933; Parker, 1918) has been found to be actually $J$. semiglobosa, an entirely distinct species. J. pseudosabina has been reported from Kashmir by many previous workers (Mehra, 1988; Gaussen, 1968; Lambert, 1933; Gamble, 1902; Hooker, 1888), but we have not found it in the valley. Also, Juniperus chinensis reported by Singh et al. (2018) to exist in wild in Kashmir Himalaya is doubtful, as it has been recorded to exist in cultivation only.

\section{Acknowledgement}

Authors are grateful to Head Department of Botany, University of Kashmir Srinagar and Principal Abdul Ahad Azad Memorial Govt. Degree College Bemina Srinagar for providing the necessary facilities to realize present sudy.

Conflict of Interest. The authors declare no conflict of interest.

\section{References}

Ara, S., Naqshi, A.R., Baba, M.Y. 1995. Indigenous and Exotic Trees, and Shrubs of Kashmir Valley, Higher Plants of Indian Sub-Continent, pp. 233272, vol. 5, Bishen Singh Mahendra Pal Singh, Dehru Dun, India.

Bhat, N.A. 1984. Floristic composition of Gulmarg (Baramulla district). Ph.D. Thesis. University of Kashmir Srinagar, Jammu and Kashmir, India.

Brandis, S.D. 1921. Indian Trees, pp. 52-53, Archibald Constable and Co. Ltd., London, UK. 
Brandis, D. 1906. Indian Trees, pp. 688-698, Archibald Constable and Co. Ltd., London, UK.

Brandis, D. 1874. Forest Flora of North West and Central India, pp. 49-52, W. H. Allen and Co., London, UK.

Christenhusz, M.J.M., Byng, J.W. 2016. The number of known plant species in the world and its annual increase. Phytotaxa, 261: 201-217.

Dallimore, W., Jackson, A.B. 1966. A Handbook of Coniferae, and Ginkgoaceae, pp. 1-280, $3^{\text {rd }}$ edition, Revised by S. G. Harrison, Edward Arnold, London, UK.

Dallimore, W., Jackson, A.B. 1948. Handbook of Coniferae, pp. 1-250, Edward Arnold, London, UK.

Dar, A.R., Dar, G.H. 2011. The giant Sequoia in the Kashmir valley. Indian Forester, 137: 907-912.

Dar, A.R., Dar, G.H. 2006. Taxonomic appraisal of conifers of Kashmir Himalaya. Pakistan Journal of Biological Sciences, 9: 859-867.

Dar, A.R., Dar, G.H. 2005. Note on the occurrence of Taxodium distichum (L.) Rich. (Taxodiaceae) in the Kashmir Himalaya. Indian Forester, 131: 967968.

Dar, A.R. 2004. Taxonomic studies on Gymnosperms in Kashmir. M. Phil. Thesis. Dissertation, Department of Botany, University of Kashmir, Jammu and Kashmir, India.

Dar, G.H., Christenson, K.I. 2003. Gymnosperms of the Western Himalaya. I. The genus Juniperus (Cupressaceae). Pakistan Journal of Botany, 35: 283-311.

Dar, G.H., Bhagat, R.C., Khan, M.A. 2002. Biodiversity of the Kashmir Himalaya, pp. 107-109, Valley Book House, Srinagar, Jammu and Kashmir, India.

Dhar, U. 1978. Phytogeographic studies on the Alpine flora of Kashmir Himalayas. Ph.D. Thesis, University of Kashmir, Srinagar, Jammu and Kashmir, India.

Dhar, G.L. 1975. Sequoiadendron giganteum- A report from Kashmir. Indian Forester, 101: 562-564.

Dhar, G.L. 1966. The distribution of coniferales in India Part. I. Pinaceae. Kashmir Science, 3: 33-42.

Drury, C.B. 1869. Handbook of the Indian Flora, pp. 267, vol. 3, Richardson and Co., London, UK.

Elwis, J.H., Henery, A. 1906-1913. Trees of Great Britain and Ireland, pp. 1-359, vol. 1-7, Edinburgh, UK.

Farjon, A. 2010. A Handbook of World's Conifers, pp. 55-1032, vol. 1 \& 2, Koninklijke Brill, N.V., Leiden Academic Publishers, Netherland.
Gamble, J.S. 1902. A Manual of Indian Trees, pp. 693722, Sampson Low, Marston and Co. London, UK.

Gaussen, H. 1968. Les Gymnospermes actuelles et fossiles. In Trav. Lab. Forest., fascicule 10, chap. 13, Toulouse, France.

Hooker, J.D. 1888. Flora of British India, pp. 640-658, vol. 5, L. Reeve and Co., London, UK.

Husain, M. 2001. Geography of Jammu and Kashmir, pp. 28, Rajesh Publications, New Delhi, India.

Jain, K.K. 1976. A taxonomic revision of the Himalayan Junipers. Indian Forester, 102: 109-118.

Javeid, G.N. 1970. Flora of Srinagar, A phytogeographic and taxonomic study of the flowering plants of Srinagar. vol. II, Ph.D. Thesis. Department of Botany, Kashmir University Srinagar, Jammu and Kashmir, India.

Javeid, G.N. 1979. Forest flora of Kashmir: A checklist II. Indian Forester, 105: 148-170.

Kaul, V., Sarin, Y.K. 1974. Studies on the vegetation of Bhaderwah Hills. I. Altitudinal Zonation. Botanical Notiser, 126: 500-507.

Khan, Z.S. 2002. Floristic studies in the Phanerogams of Bijhama (Uri) and its adjacent areas. M.Phil Dissertation, University of Kashmir Srinagar, Jammu and Kashmir, India.

Khanday, G.H. 2002. Floristic studies of vascular and non-vascular plants of lower-mundah and adjacent areas. M.Phil. Dissertation. University of Kashmir Srinagar, J\&K, India.

Khuroo, A.A. 2003. Floristic Diversity of Langate (Kupwara), with Particular Refrence to Species Richness in Phanerogames. M. Phil. Dissertation, University of Kashmir Srinagar, Jammu and Kashmir, India.

Lakusic, B., Lakusic, D. 2011. Anatomy of four taxa of the Genus Juniperus sect. Juniperus (Cupressaceae) from the Balkan Peninsula. Botanic Serbica, 35: $145-156$.

Lambert, W.J. 1933. List of trees and shrubs for the Kashmir and Jammu forest circles, Jammu and Kashmir State. Forest Bulletin, vol. 80, Dehra Dun, India.

Lancaster, R. 1980. Trees in Kashmir. The Garden, 105: 16-20.

Mehra, P.N. 1975. Conifers of the Himalayas with particular reference to the Abies and Juniperus complexes. The Nucleus, 66: 123-139.

Mehra, P.N. 1988. Indian Conifers, Gnetophytes and Phylogeny of Gymnosperms, pp. 1-264, Pramodh P. Kapur, Raj Bandra Industrial Company, 
New Delhi, India.

Page, C.N. 1979. The herbarium preservation of conifer speciemens. Taxon, 28: 375-379.

Parker, R.N. 1924. The cultivation of conifers in North India. Indian Forester, 50: 617-621.

Parker, R.N. 1940. Abies spectabilis spach. and Abies pindrow spach. Indian Forester, 66: 1-3.

Polunin, O., Stainton, A. 1984. Flowers of the Himalaya, pp. 140-142, Oxford University Press, Delhi, India.

Raizada, M.B., Sahni, K.C. 1960. Living Indian Gymnosperms. Part-I (Cycadales, Ginkgoales and Coniferales). Indian Forester Records, 5: 73-148.

Rao, A.R. 1953. Some observations on the Rajmahal flora. The Palaeobotanist, 2: 25-28.

Rodgers, W.A., Panwar, H.S. 1988. Biogeographical Classification of India, 37 pp., Wildlife Institute of India, Dehradun, India.

Sahni, K.C. 1990. Gymnosperms of India, and Adjacent Countries, pp. 1-169, Bishen Singh Mahendra Pal Singh, Dehra Dun, India.

Singh, B., Sultan, P., Bedi, Y.S. 2018. Juniperus chinensis L. (Cupressaceae): a new taxa record for Himalaya and extension of Geographic distribution in south Asia. National Academy Science Letters, 41: 6973.
Singh, G., Kachroo, P. 1976. Forest Flora of Srinagar, and Plants of Neighbourhood, pp. 229-231, Bishen Singh Mahendra Pal Singh, Dehra Dun, India.

Singh, J.B., Kachroo P. 1994. Forest Flora of Pir Panjal Range, pp. 158-159, Bishen Singh Mahendra Pal Singh, Dehra Dun, India.

Srivastava, R.C. 2006. Diversity and economic importance of living gymnosperms in India. National Academy Science Letters, 29: 75-84.

Stewart, R.R. 1972. An annotated catalogue of the vascular plants of West Pakistan and Kashmir. In: Flora of West Pakistan, S. I. Ali, E. Nasir (eds.), pp. 22-27, Fakhri Printing Press, Karachi, Pakistan.

Tewari, L.M., Jalal, J.S., Kumar, S., Pangtey, Y.P.S., Kumar, R. 2010. Wild and exotic gymnosperms of Uttarakhand, Central Himalaya. Journal of Economic and Taxonomic Botany, 4: 32-36.

Troup, R.S. 1921. Silviculture of Indian Trees, pp. 1200, vol. 3, London, UK.

Turrill, W.B. 1937. Contribution to the botany of Athos Peninsula. Kew Bulletin, 270-271.

Wali, M.K., Tiku, P.N. 1964. Contribution to the flora of Kashmir- Lolab valley. Bulletin Botanical Survey India, 6: 141-149. 